Original Article

\title{
The effects of a 6-week strength and endurance circuit training intervention on body image in Slovak primary school girls
}

\author{
LUCIA PLEVKOVÁ ${ }^{1}$; JANKA PERÁČKOVÁ ${ }^{2}$; PETRA PAČESOVÁ ${ }^{3}$; KLAUDIA KUKUROVÁ ${ }^{4}$; \\ OLYMPIA MÓKUŠOVÁ ${ }^{5}$ \\ 1,2,3,4,5, Department of Sport Educology and Sport Humanities, Faculty of Physical Education and Sport, \\ Comenius University in Bratislava, SLOVAKIA
}

Published online: April 30, 2018

(Accepted for publication April 11,, 2018)

DOI:10.7752/jpes.2018.s164

\begin{abstract}
This study examined the effect of 6-week strength and endurance circuit training (twice a week) on body image in 53 primary school girls aged 14-15 years divided in three groups ( 2 experimental and 1 control). Methods: A pre-test, post-test design was used in the 3 groups experiment. Body Mass Index (objective indicator of body image) and Contour drawing rating scale (subjective indicator) were administered as pre and post-test to each group before the intervention and after 6 weeks of intervention. Wilcoxon signed-rank test was used (SPSS version 23.0) to compare pre and post test data and to found out the differences before and after intervention in each groups. Strength and endurance circuit training was associated with significant decrease of body dissatisfaction in both experimental groups $(1: Z=2.33 ; p \square .05$ and $2: Z=2.88 ; p \square .01)$ and no changes were found in control group $(Z=.00 ; p=1.00)$. A Kruscal-Wallis test revealed that there was a significant difference in BMI among three groups $\left(\mathrm{H}(2)=6,01 ; \mathrm{p}=.049 ; \eta^{2}=0,3\right)$.

Keywords: body dissatisfaction, body mass index, current and ideal body size, exercise intervention, school physical education
\end{abstract}

\section{Introduction}

Physical activity and its benefits are known from the evidence of the amount of research articles. Nowadays everybody knows a lot of benefits of regular exercise, including numerous physical and psychological profits (Raglin, 1990; Biddle, 1993; Fox, 1999; Warburton, D. E. R., Nicol C. W., \& Bredin, S. S. D., 2006). Under the psychological profits we understand greater levels of general well being, greater positive mood, and lower levels of depression (Reed \& Ones, 2006). Physical activity can be beneficial in improving one's body image (Kirkcaldy, Shephard, \& Siefen, 2002; Gehrman et al., 2006; McIntyre, F., Chivers, P., Larkin, D., Rose, E., \& Hands, B., 2015 ).

Body image was a concern for respondents to the Youth Survey 2016 and was a concern for a higher proportion of young women $(41.4 \%)$ than young men $(17.0 \%)$. Young people continue to nominate coping with stress (44.4\% of respondents), school or study problems $(37.8 \%$ of respondents) and body image (30.6\% of respondents - extremely concerned $13.0 \%$ very concerned $17.6 \%$ ) as their top three issues of personal concern (Bailey et al. 2016). Many young people also highlighted discrimination on the basis of their appearance. Negative body image can result in social isolation or can exhibit self-destructive behaviours.

Negative body image has been associated with poor self-esteem (Franzoi and Shields 1984). Ekeland et al. (2005) analysed twenty three randomised trials and determined that exercise may have short term beneficial effects on self-esteem in children and adolescents. Study from Wilkosz et al. (2011) has found that $24 \%$ adolescent girls were dissatisfied with their bodies. Martin \& Lichtenberger (2002) proposed intervention of exercise for improving satisfaction with body. Hausenblas \& Fallon (2006) added that exercise improves body image, particularly among women. Physical exercise can have reinforcing effect on immediate body image and mood improvement (Vocks, Hechler, Rohrig \& Legenbauer, 2009). A lot of studies mentioned the positive relationships between physical activity and satisfaction with body in adolescents (Campbell \& Hausenblas, 2009). Body image and physical activity is associated. Finne et al. (2011) discovered associations between dissatisfaction with body and low level of physical activity among 11-17 years girls and similar results founded Fountoulakis and Grogan (2014). Olchowska-Kotala and Chromik (2014) stated that body satisfaction grows together with increasing the amount of time spent on physical activity.

But in current researches is necessary to prove different form of physical activity in the context of body image among women of different age groups.

Stice (2002) presents that negative body image is a major risk element for eating disorders.

Zabinski et al. (2011) found that a physical activity had no changes in body dissatisfaction (sample: men and woman, average of age $\mathrm{M}=24 \pm 1.95$ years).

Fewer researches have been conducted with adolescent girls. 


\section{LUCIA PLEVKOVÁ; JANKA PERÁČKOVÁ; PETRA PAČESOVÁ; KLAUDIA KUKUROVÁ; OLYMPIA MÓKUŠOVÁ}

\section{Materials and methods \\ Participant}

Fifty three female students from three $9^{\text {th }}$ classes of primary schools (age from 14 to 15 years) from capital town of Slovakia Bratislava. Every class was assigned to one of three groups: experimental (intervention) group 1, 2 and control group.

Experimental (intervention) group 1: fifteen female students $\left(\mathrm{M}_{\text {age }}=14.33 \pm 0.49\right.$ years, $\mathrm{M}_{\text {height }}=162.13 \pm 6.77$ $\mathrm{cm}, \mathrm{M}_{\text {weight }}=54.52 \pm 8.96 \mathrm{~kg}$ ).

Experimental (intervention) group 2: twenty female students $\left(\mathrm{M}_{\text {age }}=14.75 \pm 0.44\right.$ years, $\mathrm{M}_{\text {height }}=162.95 \pm 6.91$ $\mathrm{cm}, \mathrm{M}_{\text {weight }}=57.78 \pm 4.33 \mathrm{~kg}$ ).

Control group: eighteen female students $\left(\mathrm{M}_{\text {age }}=14.39 \pm 0.50\right.$ years, $\mathrm{M}_{\text {height }}=161.75 \pm 7.41 \mathrm{~cm}, \mathrm{M}_{\text {weight }}=54.17 \pm$ $5.48 \mathrm{~kg})$.

Every group had two lessons of physical education weekly, in duration 45 minutes.

The study included all girls whose parents gave us Informed consent (Sakáčová, 2017) to participate in our study. The girls were physically healthy and they regularly attended physical education lessons. Participant had to fulfil these two conditions to remain in our study:

1. To take part in 10 from 12 physical education lessons of every periods.

2. To take part in a gaining of every test requirements.

Test information and measurements were realized from December 2015 to March 2016 in standard conditions of regular physical education lessons. We personally took part in every measurement and we leaded strength and endurance circuit training intervention in physical education lessons.

\section{Measures}

\section{Objective measures of Body Image - Somatometry}

Body height

Before measure we prepared the height measurement on the wall and on the floor (booth with flat surfaces). Girls removed their shoes and stood with feet together against the wall. They had to look straight ahead (the line of sight had to be parallel with the floor) and had to touch the wall with their head, back, buttock and heels. Then we used rectangular triangle to form a right angle with the height measurement on the wall body height was the distance between floor and highest point on cranium (vertex). The body height was measured to the nearest 0.5 centimetre.

Body weight

We placed digital scale on the floor. Girls removed shoes and heavy clothing. They were only in typical physical education kit (T-shirt, leggings). Then they stood still with both feet in the centre of the digital scale. We measured the body weight to the nearest 0.1 kilogram.

Weight status - Body mass index

Body mass index (BMI) was determined as $\mathrm{kg} / \mathrm{m}^{2}$ - girl's body weight divided by their square of body height in metres. Then the participants were classified to 4 groups: underweight, normal (healthy) weight, overweight and obese girl students.

\section{Subjective measures of Body Image - Silhouettes}

\section{Contour Drawing Rating Scale (CDRS)}

Technique of silhouettes is the most used method for measure and orientation body dissatisfaction (Fialová, 2012; Thomson \& Gray, 1995). This method consisted of 9 silhouette figure drawings ranging from thin to fat (Fig. 1). Girls chose one silhouette in two steps: first they chose the figure that is the most obvious their actual figure (current body size), in the second step they chose the figure that they would like to look like (ideal body size). After choices we calculated current - ideal discrepancy as the discrepancy between current and ideal body size what means degree of dissatisfaction with own body size. The difference between the two ratings is used as an index of dissatisfaction (Thomson \& Gray, 1995). Test-retest reliability for current size, ideal size and current-ideal size discrepancy mostly exceeded 0.70 (Wertheim, Paxton \& Tigner, 2004). The study supported the use of the Contour Drawing Rating Scale in early adolescent girls.

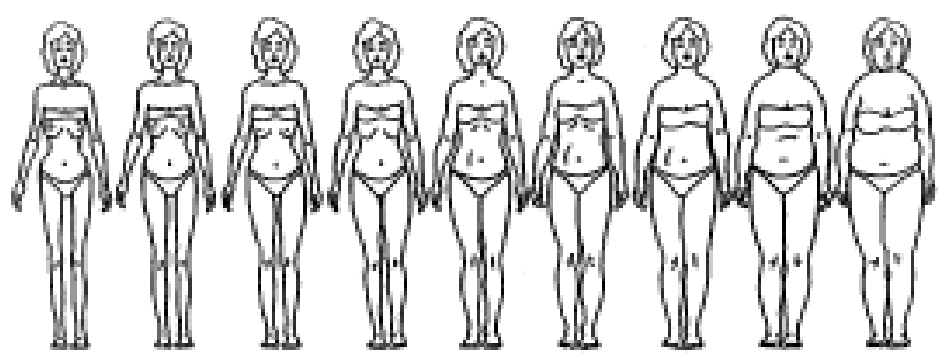

Procedure

Fig. 1 Contour Drawing Rating Scale (CDRS) (Thomson \& Gray, 1995) 
Somatometrie and CDRS from each girl was examined pre- and post-intervention.

Experimental groups participated in strength and endurance circuit training. Physical education lessons with this program were performed twice a week for 6 weeks. Each lesson lasted 45 min and consisted of:

a) warm up (5-12 $\mathrm{min})$,

b) strength endurance circuit training (20-35 $\mathrm{min})$,

number of exercises: 6-12 (Sedláček, Lednický, 2010), number of circles: 2-3, work cycle for each exercise: 30 seconds, recovery cycle between 2 exercises: 15 second, recovery cycle between 2 circles: 2 minutes, example of exercises: lot of variations of squats, push ups, lunges, sit ups, exercises with Swiss ball, overball, etc.

c) cool down and stretching (3-10 min).

All physical education lessons were conducted in a school sports hall.

The control group did not participate in the strength and endurance circuit training, they had only typical curricular exercise and sports -4 lessons of athletics, 2 lessons of gymnastics and 6 lessons of volleyball.

\section{Statistical analysis}

Data were analyzed with statistical program SPSS 23. Wilcoxon T-test (non-parametric method) was used for comparison pre-test and post-test measurements in every group and Kruscal-Wallis H-test (nonparametric method) was used to determine statistically significant differences in changes among 3 groups (experimental group 1 and 2 and control group) and 2 variables (pre-test and post-test score of BMI and degree of body dissatisfaction measured as a discrepancy between current and ideal body size marked on CDRS).

\section{Results}

\section{Objective indicator of Body image - Body Mass Index}

$13 \%$ of girls from experimental group were overweight, the rest ( $87 \%$ of girls) were classified as normal weight. Girls from experimental group 2 were classified as follow: $80 \%$ as normal weight, $15 \%$ as overweight and $5 \%$ as obese. Our control group consisted of only normal weight girls. The same weight classification of girls from experimental groups was before and after intervention. Average BMI in each group is presented in Tab. 1 .

Table 1. Body Mass Index

\begin{tabular}{lllll}
\hline & Pre & & Post & \\
\cline { 2 - 5 } & M & SD & M & SD \\
\hline Experimental group 1 & 20.68 & 2.74 & 20.74 & 2.74 \\
\hline Experimental group 2 & 21.88 & 2.60 & 21.84 & 2.54 \\
\hline Control group & 20.66 & 0.83 & 20.63 & 0.84 \\
\hline
\end{tabular}

The Wilcoxon test results revealed no significant effect on BMI in pre- and post-test in every group. Values of BMI were relatively stable - experimental group 1 worsened in BMI average (0.06) when we compare BMI before and after intervention. Experimental group 2 increased BMI by 0.04 and control group by 0.03 . But the Kruscal-Wallis H-test results revealed significant changes in comparison of experimental group 1 and control group $(\mathrm{p}<0.05)$. Comparison of experimental group 1 and experimental group 2 revealed no significant changes, the same comparison with no significance was revealed in experimental group 2 and control group.

\section{Subjective indicator of Body image - Silhouettes}

There were significant differences between pre- and post-test data in both experimental group, but differences in control group were not significant.

Table 2. $\quad$ Contour drawing rating scale

\begin{tabular}{lllll}
\hline & Pre & & Post & \\
\cline { 2 - 5 } & $\mathbf{M}$ & SD & M & SD \\
\hline Experimental group 1 & 1.47 & 1.36 & 1.00 & 1.36 \\
\hline Experimental group 2 & 0.95 & 1.05 & 0.45 & 0.76 \\
\hline Control group & 0.83 & 0.92 & 0.84 & 0.86 \\
\hline
\end{tabular}

In experimental group 1 girls ranged their body dissatisfaction from 0 to 5 points (the highest possible 8) before application intervention and from 0 to 5 after intervention - differences were in average, because pretest average was 1.47 points $(\mathrm{SD}=1.36)$ and post-test average 1.00 points $(\mathrm{SD}=1.36)$. The average in degree of body dissatisfaction decreased 0.47 point. The highest decrease was from 3 points to 1 point. Three girls showed no point differences between pre-test and post-test designation. There was no notice that any girl increased the degree of body dissatisfaction after intervention. In this group were a significant differences between pre- and post-test $(\mathrm{p}<0.05)$.

In experimental group 2 participants ranged degree of body dissatisfaction with their body from 0 to 4 in pre-test and from 0 to 3 in post-test. The average score in the degree of body dissatisfaction was 0.95 points 


\section{LUCIA PLEVKOVÁ; JANKA PERÁČKOVÁ; PETRA PAČESOVÁ; KLAUDIA KUKUROVÁ; OLYMPIA MÓKUŠOVÁ}

$(\mathrm{SD}=1.05)$ before the exercise intervention and 0.45 points $(\mathrm{SD}=0.76)$ after the 6 -week strength and endurance circuit training. The average decrease was higher $(0.50$ point $)$ than in experimental group 1 . The highest decrease was 2 points and after intervention 13 girls from the experimental group 1 designed the degree of body dissatisfaction with the 0 point, they were satisfied. Equally in this group 2 there was no notice the increase in degree of body dissatisfaction among girls. Differences between pre and post-test were statistically significant $(\mathrm{p}<0.01)$.

Control group ranged the degrees of body dissatisfaction in pre- and post-test from 0 to 3 points, while pre-test average was 0.83 points $(\mathrm{SD}=0.92)$ the post-test average was 0.84 points $(\mathrm{SD}=0.86)$. The scores on the Contour drawing rating scale in this group remained relatively stable pre- and post-test (mean difference only 0.1 points). One girl from the control group increased degree of body dissatisfaction, one degreased, and others were on the same status. Differences were not statistically significant.

Strength and endurance circuit training was associated with significant decrease of body dissatisfaction in both experimental groups $(1: \mathrm{Z}=2.33 ; \mathrm{p} \square .05$ and $2: \mathrm{Z}=2.88 ; \mathrm{p} \square .01)$ and no changes were found in control group $(Z=.00 ; p=1.00)$. A Kruscal-Wallis test revealed that there was a significant difference in BMI among three groups $\left(\mathrm{H}(2)=6,01 ; \mathrm{p}=.049 ; \eta^{2}=0,3\right)$. Results of Kruscal-Wallis H-test, which compared differences in changes between 3 groups, revealed that there was decrease in degree of body dissatisfaction in both experimental group, but these changes were not significant in comparison to the control group.

These findings suggest that strength and endurance circuit training can improve satisfaction with body of primary school girls due to decrease of their index of body dissatisfaction.

\section{Discussion}

The current study was designed to examine the effects of 6-weeks strength endurance circuit training intervention on body image among primary school girls. It was hypothesized that the intervention (strength endurance circuit training) would have a significant positive impact on this dependent variable (body image) in experimental groups, while control group would not change. In accordance with this hypothesis, the results revealed, that participation in 6-week strength circuit training on physical education lesson enhanced body image of 14-15-year old females.

Available researches and studies have reported contradictory findings. Some of them have demonstrated significant relationship between physical activity and body image (Burgess, Grogan \& Burwitz, 2006; Fountoulakis \& Grogan, 2014). Some have reported no significant improvement of body image or no changes after physical activity intervention (Aşçi, Kin, \& Koşar, 1998; Zabinski et al. 2011). Pačesová (2016a) found that nonsporting adolescent girls were more satisfied with overall body shape than female sport active adolescents. Results of Pačesová (2016b) study showed higher level of satisfaction in group of nonathletes in every surveyed body part except one. Cohn et al. (1987) found no significant difference between actual and ideal figure in 10.515 -year-old girls, although $38 \%$ had thinner ideal than their current figure. More current studies incline to positive impact physical activity on body image, especially among female (Tucker \& Maxwell, 1992; Tucker \& Mortell, 1993; Williams \& Cash, 2001; Abbott \& Barber, 2011; Peráčková \& Peráček; 2016; Nayir et al., 2016). The results of the study of Duncan et al. (2009) stated that, as compared to the control group, participants in 6week circuit training significantly improved body esteem scores post intervention. Circuit training participants in study of Sothern (2014) decreased waist circumference subcutaneous adipose tissue and this is for better appearance. All exercise trials (aerobic session, interval circuit and resistance exercise) in Hubbard study (2013) yielded significantly different scores post activity as compared to the control trial. Even a relatively brief weight training program can produce improvements in multiple aspects of body image (Williams and Cash 2001). Tucker and Maxwell (1992) presented effects of 15-week, two-day-per-week weight training activities which improved body image. Another study (Henry, Anshel and Michael 2006) determined 12-week aerobic and interval circuit training on fitness and body image among women. The interval circuit training group experienced the greatest improvement for the body image. Maher, Pincus, Ram and Conroy (2015) study added evidence that daily fluctuations in physical activity had important implications for well-being regardless of age.

In general, this study found that 6-week strength and endurance circuit training did significantly improve body image of 14-15 years old primary school girls. The same results noted Williams \& Cash (2001) those 6-week circuit-weight training program improved body image in 39 college students (sample included booth gender - 27 women, 12 men). These findings are in opposition to study Caruso and Gill (1993) that reported no significant changes in body image following 10 -week weight training in undergraduate females. In the context with previous studies, it is important to ask a question, whether some kinds of physical activity are better for improving the body image in adolescent females than other.

For example Aşçi, Kin, Koşar (1998) reported no significant effect of 8-week aerobic dance on body image in 45 female university students. On the other hand Burgess, Grogan, Birwitz (2006) revealed improvement of body image dissatisfaction after 6-week aerobic dance intervention in 13-14 years girls (aerobic dance were performed twice a week, in duration $50 \mathrm{~min}$ ). Monteiro Gaspar et al. (2011) discovered that higher levels of physical activity in children (10-17 years) had a protective effect on body image dissatisfaction There is practical implication from this study for teachers or trainers. 


\section{LUCIA PLEVKOVÁ; JANKA PERÁČKOVÁ; PETRA PAČESOVÁ; KLAUDIA KUKUROVÁ; OLYMPIA MÓKUŠOVÁ}

\section{Conclusion}

Strength and endurance circuit training applied twice a week in a 6 week lasting involved during the physical education lessons among early adolescent girls revealed positive effects on body image. Early adolescent girls, who finished training program, reported significantly decrease of discrepancy between current and ideal figures after 6 week strength and endurance circuit training in comparison to early adolescent girls from control group, who attend traditional physical education lesson without strength and endurance circuit training. For future study we suggest verification of the strength and endurance circuit training for a longer period and try it also among girls from control group.

\section{Acknowledgments}

This study was supported by VEGA Grant No.: 1/0726/17 the Comenius University in Bratislava (Sports motivational profile for different groups of population and the influence of various sport activity to improve the subjective dimension of quality of life).

\section{References:}

Abbott, B. D., \& Barber, B. L. (2011). Differences in functional and aesthetic body image between sedentary girls and girls involved in sports and physical activity: Does sport type make a difference? Psychology of Sport and Exercise, 12(3), 333-342.

Aşçi, F. H., Kin, A., \& Koşar, N. S. (1998). Effect of participation in an 8 week aerobic dance and step aerobics program on physical self-perception and body image satisfaction. International journal of sport psychology, 29(4), 366-375.

Bailey, V., Baker, A-M., Cave, L., Fildes, J., Perrens, B., Plummer, J., \& Wearing, A. (2016). Mission Australia's 2016 Youth Survey Report, Mission Australia. Sydney: Mission Australia.

Biddle, S. J. H. (1993). Children, exercise and mental health. International Journal of Sport Psychology, 24, 200-216.

Burgess, G., Grogan, S., \& Burwitz, L. (2006). Effects of 6-week aerobic dance intervention on body image and physical self-perceptions in adolescent girls. Body image, 3(1), 57-66.

Campbell, A., \& H.A. Hausenblas (2009). Effects of exercise interventions on body image: A meta-analysis. Journal of Health Psychology, 14(6), 780-793.

Caruso, C. M., \& Gill, D.L. (1993). Strengthening self-perceptions thouh exercise. The Journal of sport medicine and physical fitness, 32(4), 416-427.

Cohn, L. D., Adler, N. E., Irwin, Ch. E. Jr., Millstein, S. G., Kegeles, S. M., \& Stone, G. (1987). Body-Figure Preferences in male and female adolescents. Journal of Abnormal Psychology, 96(3), 276-279.

Duncan, M. J., Al-Nakeeb, Y., \& Nevill, A. M. (2009). Effects of a 6-week circuit training intervention on bodyesteem and body mass index in British primary school children. Body Image, 6(3), 216-220.

Ekeland, E., Heian, F. \& Hagen, K. B. (2005). Can exercise improve self esteem in children and young people? A systematic review of randomised controlled trials. British Journal of Sports Medicine, 39(11), 792-798.

Fialová, L. (2012). Pojetí vlastního těla. Zdraví, zdatnost, vzhled. [The concept of own body. Health, fitness, appearance]. Praha: Karolinum.

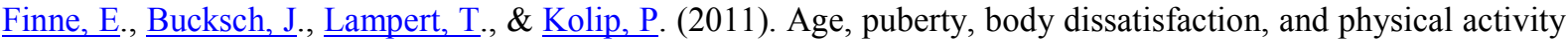
decline in adolescents. Results of the German Health Interview and Examination Survey (KiGGS). The International Journal of Behavioral Nutrition and Physical Activity, 8(1), 119-133.

Fountoulakis, C., \& S. Grogan, (2014). An investigation of the links between body image and exercise participation. Sport \& Exercise Psychology Review, 198(11), 19-30.

Fox, K. R. (1999). The influence of physical activity on mental well-being. Public Health Nutrition, 2(3a), 411418.

Franzoi, S. L., \& Shields, S. A. (1984). The body esteem scale: multidimensional structure and sex differences in a college population. Journal of Personality Assesment, 48(2), 173-178.

Gehrman, C. A., Hovell, M. F., Sallis, J. S., \& Keating, K. (2006). The effects of a physical activity and nutrition intervention on body dissatisfaction, drive for thinness, and weight concerns in pre-adolescents. Body Image, 3(4), 345-351.

Hausenblas, H. A., \& E. A. Fallon (2006). Exercise and body image: A metaanalysis. Psychology and Health, 21(1), 33-47.

Henry, R. N., Anshel, M. A., \& Michael, T. (2006). Effects of Aerobic and Circuit Training on Fitness and Body Image Among Women. Journal of Sport Behavior, 29(4), 281-303.

Hubbard, E. A. (2013). The Effects of Exercise Modality on State Body Image. Graduat Theses and Dissertations.

Retrieved

from http://scholarcommons.usf.edu/cgi/viewcontent.cgi? article=5706\&context $=$ etd

Kirkcaldy, B. D., Shephard, R. J., \& Siefen, R. G. (2002). The relationship between physical activity and selfimage and the problem behavior among adolescents. Soc Psychiatry Psychiatr Epidemiol, 37, 544-550. 


\section{LUCIA PLEVKOVÁ; JANKA PERÁČKOVÁ; PETRA PAČESOVÁ; KLAUDIA KUKUROVÁ; OLYMPIA MÓKUŠOVÁ}

Maher, J. P., Pincus, A. L., Ram, N., \& Conroy, D. E. (2015). Daily Physical Activity and Life Satisfaction across Adulthood. Developmental Psychology, 51(10), 1407-1419.

Martin, K. A., \& Lichtenberger, C. M. (2002). Fitness enhancement and changes in body image. In Cash T. F., \& Pruzinsky T. (Eds.), A handbook of theory, research, and clinical practice (pp. 414-421). New York, NY: The Guilford Press.

McIntyre, F., Chivers, P., Larkin, D., Rose, E., \& Hands, B. (2015). Exercise can improve physical self perceptions in adolescents with low motor competence. Human Movement Science, 42, 333-343.

Monteiro Gaspar, M. J., Amaral, T. F., Oliveira, B. M. P. M., \& Borges, N. (2011). Protective effect of physical activity on dissatisfaction with body image in children - A cross-sectional study. Psychology of Sport and Exercise, 12(5), 563-569.

Nayir, T., Uskun, E., Yürekli, M. V., Devran, H., Çelik, A., \& Okyay, R. A. (2016). Does Body Image Affect Quality of Life?: A Population Based Study. PLoS ONE, 11(9), 1-13. doi: 10.1371/journal.pone.0163290.

Olchowska-Kotala, A., \& Chromik, K. (2014). Body satisfaction and time spent on physical activity in Polish students. Human Movement, 14(4), 285-290.

Pačesová, P. (2016a). Spokojnost' s telom adolescentiek z hl'adiska vykonávania športovej activity [Body satisfaction of adolescent girls in therms of sport activity]. In: Peráčková et al. Telesné sebaponímanie školskej športujúcej a něsportujúcej populácie [Physical self-perception of school sport active and sport inactive population]. Bratislava: Vydavatel'stvo Univerzity Komenského. pp. 156-162.

Pačesová, P. (2016b). Spokojnost' s telom adolescentov z hl'adiska vykonávania športovej activity [Body satisfaction of adolescent boys in therms of sport activity]. In: Peráčková et al. Telesné sebaponímanie školskej športujúcej a nešportujúcej populáre [Physical self-perception of school sport active and sport inactive population]. Bratislava: Vydavatel'stvo Univerzity Komenského. pp. 171-176.

Peráčková, J., \& Peráček, P. (2016). Body image športujúcich a nešportujúcich adolescentov [Body image of adolescent athletes and nonathletes]. In: Peráčková et al. Telesné sebaponímanie školskej športujúcej a něsportujúcej populácie [Physical self-perception of school sport active and sport inactive population]. Bratislava: Vydavatel'stvo Univerzity Komenského. pp. 6-136.

Raglin, J. S. (1990). Exercise and mental health: benefical and detrimental effects. Sport Medicine, 9(6), 323329.

Reed, J., \& Ones, D. S. (2006). The effect of acute aerobic exercise on positive activated affect: A meta-analysis. Psychology of Sport and Exercise, 7(5), 477-514.

Sakáčová, Z. (2017). Informovaný súhlas v športe. Telesná výchova \& šport, 27(1), 2-7.

Sedláček, J., \& Lednický, A. (2010). Kondičná atletická príprava. Bratislava: Slovenská vedecká spoločnost' pre telesnú výchovu a šport.

Sothern, M. S. (2014). Effective Exercise for Overweight Youth. Boca Raton: CRC Press, Tylor\&Francis Group.

Stice, E. (2002). Risk and maintenance factors for eating pathology: A meta-analytic review. Psychological Bulletin, 128(5), 825-848.

Thomson, M., A. \& Gray, J. J. (1995). Development and validation of a new body-image assessment scale. Journal of Personality Assessment, 64(2), 258-269.

Tucker, L. A., \& Maxwell, K. (1992). Effects of weight training on the emotional well-being and body image of females: predictors of greatest benefit. American Journal of Health Promotion, 6(5), 338-344.

Tucker, L. A., \& Mortell, R. (1993). Comparison of the effects of walking and weight training programs on body iamge in middle-aged women: an experimental study. Am J Health Promot, 8(1), 34-42.

Vocks, S., Hechler, T., Rohring, S., \& Legenbauer, T. (2009). Effects of a physical exercise session on state body image: The influence of pre-experimental body dissatisfaction and concerns about weight and shape. Psychology \& Health, 24(6), 713-728.

Warburton, D. E. R., Nicol C. W., \& Bredin, S. S. D. (2006). Health benefits of physical activity: the evidence. CMAJ, 174(6), doi: 10.1503/cmaj.051351.

Wertheim, E. H., Paxton, S. J., \& Tigner, L. (2004). Test-retest reliability and construct validity of Contour Drawing Rating Scale scores in a sample of early adolescent girls. Body Image. 1(2), 199-205.

Wilkosz, M., Chen, J., Kenndey, C., \& Rankin, S. (2011). Body dissatisfaction in California adolescents. Journal of the American Association of Nurse Practitioners, 23(2), 101-109.

Williams, P. A., \& Cash, T. F. (2001). Effects of circuit weight training program on the body images of college students. International Journal of Eating Disorder, 30(1), 75-82.

Zabinski, M.F., Calfas, K.J., Gehrman, C.A., Wilfley, D.E., \& Sallis, J.F. (2011). Effects of a physical activity intervention on body image in university seniors: Project GRAD. Annals of Behavioral Medicine, 23(4), $247-252$. 